\title{
Microbiological assessment of the effectiveness of chlorhexidine mouthrinse before taking impressions of the oral cavity
}

\author{
Avaliação microbiológica da eficácia do bochecho de \\ clorexidina prévio à moldagem da cavidade bucal
}

\begin{abstract}
Purpose: The aim of this study is to assess the reduction of microbial load that adhered to irreversible hydrocolloid impressions obtained after rinsing with $0.12 \%$ and $0.2 \%$ chlorhexidine solutions.

Methods: The study consisted of 24 participants (48 dental arch impressions) equally divided into two groups: Group 1 (0.12\% chlorhexidine) and Group 2 (0.2\% chlorhexidine). The impressions were taken using Hydrogun ${ }^{\circledR}$ irreversible hydrocolloid before (control) and after (experimental) a single $10 \mathrm{~mL}$ mouthrinse of chlorhexidine for 1 minute. Each impression was placed in a sterile beaker containing $250 \mathrm{ml}$ of saline. The microbiological analysis of the storage solution was carried out using $\mathrm{BHI}$ Agar culture medium. The plates were incubated for 24 hours, followed by a CFU (Colony Forming Units) count. The data were analyzed using the Wilcoxon's † test.

Results: There was a reduction in the degree of contamination of the impressions after rinsing with the antimicrobial mouth rinses at both concentrations when compared with the control group. There was a statistically significant difference when the effectiveness of the two concentrations used was compared.
\end{abstract}

Conclusion: Therefore, using a chlorhexidine rinse prior to obtaining irreversible hydrocolloid impressions reduces contamination and is more efficient at the $0.2 \%$ concentration.

Key words: Exposure to biological agents; chlorhexidine; irreversible hydrocolloid

\section{Resumo}

Objetivo: $O$ objetivo deste estudo é avaliar a redução da carga microbiana aderida nos moldes de hidrocolóide irreversível obtidos após bochecho com clorexidina nas concentrações $0,12 \%$ e $0,2 \%$.

Metodologia: $\bigcirc$ estudo incluiu 24 participantes (48 moldes de arcadas dentárias) divididos igualmente em dois grupos: Grupo 1 ( clorexidina 0,12\%) e Grupo 2 (clorexidina 0,2\%). As arcadas foram moldadas com hidrocolóide irreversível Hydrogun ${ }^{\circledR}$ antes (controle) e após (experimental) bochecho único com $10 \mathrm{~mL}$ de clorexidina nas concentrações específicas de cada grupo durante 1 minuto. Cada molde foi acomodado em bécker estéril contendo $250 \mathrm{~mL}$ de soro fisiológico. A partir dessa solução, realizou-se análise microbiológica em meio de cultura BHI Ágar. As placas foram submetidas a um período de incubação de $24 \mathrm{~h}$ oras, seguida de contagem das UFC (Unidades Formadoras de Colônias). Os dados foram submetidos à análise estatística aplicando o teste † de Wilcoxon.

Resultados: Observou-se redução do grau de contaminação dos moldes obtidos após bochecho com o antimicrobiano nas duas concentrações, em relação ao grupo controle e, também, diferença estatística significativa quando comparadas a eficácia das duas concentrações utilizadas.

Conclusão: $O$ bochecho de clorexidina prévio à obtenção de moldes de hidrocolóide irreversível reduz a contaminação e com melhor eficácia na concentração 0,2\%.

Palavras-chave: Exposição a agentes biológicos; clorexidina; hidrocolóide irreversível

\section{Carmem Dolores V. Soares de Moura Lorenna B. Lima Verde Nogueirab Caroline Costa do Nascimento ${ }^{c}$ Isadora Mello Vilarinho Soares c Janaína Cordeiro de Oliveira Castro a Walter Leal de Moura d}

\footnotetext{
- Department of Restorative Dentistry/CCS/ Federal University of Piauí, Teresina, Pl, Brazil b Masters course in Dentistry, Sciences and Health Centre - Dentistry, Federal University of Piauí, Teresina, Pl, Brazil

c Dental School, Sciences and Health Centre Dentistry, Federal University of Piauí, Teresina, $\mathrm{Pl}$, Brazil

dDepartment of Pathology and Dental Clinic/ CCS/Federal University of Piauí, Teresina, PI, Brazil
}

\section{Correspondence:}

Carmem Dolores Vilarinho Soares de Moura Department of Restorative Dentistry/CCS/ Federal University of Piaul

Rua São Pedro, 3274

Teresina, PI - Brasi

64001-914

E-mail: carmemdvsm@uol.com.br

Received: January 11, 2012

Accepted: April 11, 2012

Conflict of Interests: The authors state that there are no financial and personal conflicts of interest that could have inappropriately influenced their work.

Copyright: (C) 2011 Moura et al. ; licensee EDIPUCRS. This is an Open Access article distributed under the terms of the Creative Commons AttributionNoncommercial-No Derivative Works 3.0 Unported License. 


\section{Introduction}

Among the dental prosthetic procedures, taking impressions of the oral cavity is a major vector in the chain of cross infection as they can harbour contaminated saliva, blood and biofilm, which can be transmitted during handling (1).

Irreversible hydrocolloids (alginates) are some of the most critical impression materials in terms of methods of disinfection. The hydrophilic nature of this material requires great care so that the disinfection method does not affect the dimensional stability of the impressions (2). Alginates also have a structure that is similar to the polysaccharide agar, which is renowned as an excellent culture medium for bacteria, a characteristic that facilitates their participation in cross infection (1). Thus, a reduction in the microbial load of impressions would facilitate subsequent decontamination procedures.

Chlorhexidine, chemically classified as chlorhexidine digluconate, is a chemical substance that has long been used as a broad spectrum antiseptic, for both gram positive and gram negative bacteria (3). The antiseptic activity results from its ability to bind with anionic groups of the bacterial surface, causing an increase in cell permeability and thus a change in osmotic equilibrium. The chlorhexidine molecule is also able to connect to the oral mucosa, the surface of the enamel and salivary proteins. It is then slowly released into the oral cavity at an effective concentration for approximately 24 hours, which is characteristic of high substantivity (4).

Chlorhexidine is widely used to control biofilm in periodontal therapy $(5,6)$, and as an irrigation solution in endodontic therapy $(7,8)$, but its use as mouthrinse solution is the most studied and most applicable for reduction of the oral flora (9). Thus, due to its excellent antimicrobial properties, chlorhexidine mouthrinse has been used to inhibit biofilm formation in the therapy of oral infections that are already existent. However, its application has proved more valuable in prevention (3), because it promotes the reduction of microorganisms in the oral environment due to its bactericidal action (immediate) during the time of application in the oral cavity, where a substantial amount of bacteria are killed and also due to a bacteriostatic effect (9).

By using a microbiological assessment this study aims to evaluate the reduction of the microbial load that is adhered to Hydrogum ${ }^{\circledR}$ irreversible hydrocolloid impressions obtained after rinsing with $0.12 \%$ and $0.2 \%$ chlorhexidine solutions, before taking impressions of the oral cavity, in order to facilitate subsequent disinfection procedures.

\section{Materials And Methods}

This study included 24 edentulous patients (48 impressions of dental arches) at the Dental Clinic of the Federal University of Piauí. None of the participants had received previous prosthetic treatment. Such a criterion was adopted because the impressions are more easily removed from the mouth and also because of the greater accumulation of biofilm in the area of the prosthesis. All participants were individually informed about the nature, objectives and procedures of the study and signed a consent form (CEPUFPI, 29/04/2010).

Patients were divided into groups: Group $1(0.12 \%$ chlorhexidine) and Group 2 (0.2\% chlorhexidine). The impressions of each patient were taken before (control) and after (experimental) a single $10 \mathrm{~mL}$ mouthrinse of chlorhexidine. It was established that, for each group, the first six patients had the upper arch (control) impression taken first followed by the lower teeth (experimental) impression. For the last six, the reverse order was adopted.

The material used was Hydrogum ${ }^{\circledR}$ (Zermack s.p.A, Rovigo/Italy, batch 55896) irreversible hydrocolloid. It was manipulated according to manufacturer's instructions. The powder was mixed with distilled water. The silicone container, spatula, powder and water meters were previously washed with neutral detergent, dried with paper towels and protected with PVC film until ready to use. After manipulation of the material, stainless steel trays (Tenax Ltda of Brazil, Vitória, Espírito Santo - Brazil) were used to obtain the impressions. The impression of the first arch was used as control and then each participant vigorously rinsed with 10 $\mathrm{mL} 0.2 \%$ or $0.12 \%$ chlorhexidine (Virginia Regina Fortes Castelo Branco e Cia Ltda. - Galeno Pharmacy, Teresina, Piauí - Brazil) for 1 minute. Afterwards the impression of the second arch was taken (experimental group).

Each impression was placed in a properly labelled sterile beaker, containing $250 \mathrm{~mL}$ of saline. The beaker was taken to an ultrasound device (THORNTON-INPEC Eletrônica Ltda. São Paulo, Brazil) for 15 seconds in order to release the microbial film adhered to the impression. The microbiological assessment (10) of the saline was carried out at the Laboratory of Microbiology, Federal University of Piauí. A pipette was used to transfer $1 \mathrm{~mL}$ of the solution into a test tube containing $9 \mathrm{ml}$ of $\mathrm{NaCl} 0.9 \%$, yielding a final concentration of $10 \%$ and afterwards it was taken to the agitator (Quimis Scientific Apparatus Limited. ISO 9002, Diadema, SP, Brazil).

After the agitation, $100 \mu \mathrm{L}(0.1 \mathrm{~mL})$ of solution was collected with a tip, and was placed in a labelled Petri dish containing sterile culture medium BHI Agar (DIFCO, Detroit, Michigan, USA) and spread with a sterile pipette tip. The plates were labelled and placed in an incubator (Fanem General Electric, Guarulhos, SP, Brazil) at $37^{\circ} \mathrm{C}$ for 24 hours, to allow growth of microorganisms. After 24 hours of incubation, the plates were examined using a digital counter and magnifying glass (Quimis Scientific Equipment Ltd., ISO 9001, Diadema, SP, Brasil).

Colony forming units (CFU) were counted, defined as the minimum number of cells on the surface of semi-solid agar that give rise to a visible descendents colony (Centers for Disease Control and Prevention, 2003). Values above fifty (50) were considered uncountable. Petri dishes with BHI agar remained in an oven for 24 hours before the experiment, for certification of decontamination of the medium. All other procedures also followed biosafety standards.

The data were analyzed by using Wilcoxon's t test. 


\section{Results}

Tables 1 and 2 summarize the results. There was a reduction in the degree of contamination of the impressions after rinsing with the antimicrobial mouth rinses at both concentrations when compared with the control group. There was a statistically significant difference when the effectiveness of the two concentrations used was compared.

Table 1. Descriptive statistics (mean, standard deviation, maximum value, minimum value), Wilcoxon test $(Z)$ and $P$-value of the Colony Formation Units (CFU) of Groups 1 and 2

\begin{tabular}{ccccccc}
\hline $\begin{array}{c}\text { Groups } \\
(\mathrm{n}=12)\end{array}$ & Mean & $\begin{array}{c}\text { Standard } \\
\text { Deviation }\end{array}$ & $\begin{array}{c}\text { Maximum } \\
\text { Value }\end{array}$ & $\begin{array}{c}\text { Minimum } \\
\text { Value }\end{array}$ & $\mathrm{Z}$ & $P$ \\
\hline Group 1 (0.12\%) & & & & & & \\
Control & 24.67 & 20.45 & 50 & 3 & 2.93 & 0.0170 \\
Experimental & 5.17 & 6.83 & 25 & 0 & & \\
Group 2 (0.2\%) & & & & & & \\
Control & 9.15 & 8.84 & 26 & 1 & 3.06 & 0.0011 \\
Experimental & 1.00 & 1.21 & 4 & 0 & & \\
\hline
\end{tabular}

Table 2. Mean, Wilcoxon test $(Z)$ and $P$-value of the Colony Formation Units (CFU) of the experimental subgroups at the concentrations of $0.12 \%$ and $0.2 \%$

\begin{tabular}{cccc}
\hline Groups $(n=12)$ & Mean & $Z$ & $P$ \\
\hline $\begin{array}{c}\text { Group 1 }(0.12 \%) \\
\text { Experimental }\end{array}$ & 5.17 & & \\
$\begin{array}{c}\text { Grupo 2 }(0.2 \%) \\
\text { Experimental }\end{array}$ & 1.00 & 2.1181 & 0.0171 \\
\hline
\end{tabular}

\section{Discussion}

The effects of chlorhexidine mouthrinse on oral microflora and on biofilm development that were proven in the classic studies in the 70's (6) and over the last 40 years (11-15) justify its wide use in clinical dentistry with a preventive and therapeutic aim. In this study, the undeniable bactericidal property of chlorhexidine was tested in order to reduce the degree of contamination of irreversible hydrocolloid impressions. The reduction in the degree of contamination in irreversible hydrocolloid impressions facilitates disinfection procedures, since this material has hydrophilic properties (2) and also an intrinsic potential to retain microorganisms $(16)$.

After 24 hours, mouthrinsing with $0.2 \%$ chlorhexidine caused a reduction of $85 \%$ of the aerobic and anaerobic bacteria count in the saliva while the control group had an increase of $300 \%$ (6). This study also found that a single antimicrobial mouthrinse of the same volume and at different concentrations $(0.12 \%$ - Group 1 , and $0.2 \%$ - Group 2$)$ caused a reduction of the contamination of irreversible hydrocolloid impressions compared with the respective controls (Table 1). These findings suggest that contamination of impressions was lower due to the reduction of microorganisms in the oral cavity caused by the prompt action of the antimicrobials (4). These results are corroborated by studies that assessed the immediate effect of the use of chlorhexidine mouth rinse or topically used chlorhexidine on teeth bacterial colonization of enamel. It was found that the substance had immediate bactericidal and prolonged bacteriostatic effect, the latter due to its adsorption to biofilm adhered to the tooth surface (9).

Most studies on the effectiveness of chlorhexidine mouthrinses assess it on daily-use and long-term regimes, especially regarding periodontal therapy, with excellent results in reducing biofilm and oral pathogenic microorganisms and in restoring periodontal health $(6,12-14)$.

A smaller number of studies discuss the immediate efficacy of the antimicrobial 5 minutes after a mouthrinse. They have found that both aerobic and anaerobic bacteria have a significantly lower survival percentage than the control (17).

A classic experimental gingivitis study showed that rinsing for one minute twice a day with $10 \mathrm{ml}$ of $0.2 \%$ chlorhexidine was an effective anti-gingivitis and antiplaque method. It established $20 \mathrm{mg}$ of chlorhexidine as the standard dose per mouthrinse (6). Study has proven that the effectiveness of chlorhexidine is dose-dependent (18). Similar results to those obtained using $0.2 \%$ chlorhexidine were reached by using $15 \mathrm{ml}$ of a $0.12 \%$ solution - the equivalent to an $18 \mathrm{mg}$ dose, very close to the standard dose $(13,19)$.

In this study, because the adopted mouthrinse volume was $10 \mathrm{~mL}$, there was a statistically significant reduction in the contamination of impressions after rinsing with $0.2 \%$ chlorhexidine when compared with the $0.12 \%$ group (Table 2 ). The use of identical volumes resulted in doses of $12 \mathrm{mg}$ and $20 \mathrm{mg}$ chlorhexidine gluconate for the $0.12 \%$ and $0.20 \%$ mouthrinse products, respectively. So, the fact that the dose delivered by the concentration of $0.12 \%$ was lower than the standard concentration resulted in a lower effectiveness in reducing contamination of the impressions, when compared to the $0.2 \%$ chlorhexidine mouthrinse. 
This fact is consistent with other clinical studies on the efficacy of reducing biofilm and pathogenic microorganisms with 0.12 and $0.2 \%$ chlorhexidine mouthrinses. However, those studies did not find results that are statistically different for the different concentrations when similar doses were used, i.e., $10 \mathrm{~mL}$ of $0.2 \%$ and $15 \mathrm{~mL}$ of $0.12 \%$ (12-14). So, it is clear that a higher volume $(15 \mathrm{~mL})$ is needed when a $0.12 \%$ chlorhexidine is used in order to obtain a comparable efficacy to that of $0.2 \%$. The use of a lower concentration in order to mitigate the side effects of antimicrobial use, especially regarding changes in taste and its unpleasant taste (19), is only justified when the volume compensates for the lower concentration.

The risk of cross-infection when handling irreversible hydrocoloid impressions, the limitations of the disinfection procedures of such material and the excelent properties of chlorhexidine and its wide use in dentistry have lead researchers to test the association of both. It has been shown in vitro that alginates which incorporate chlorhexidine in the powder have lower microbial contamination when compared with alginate without chlorhexidine (1) and that the manipulation of alginate with $0.2 \%$ chlorhexidine instead of water is even more effective at reducing the contamination of impressions than adding the antimicrobial to the powder (20).

This study, which showed the efficacy of chlorhexidine mouthrinse before the impression taking procedure, may be defined as a clinical extension of the association of this material as an antimicrobial. The main advantage is the fact that there is no risk of physical alteration of the impressions, and, therefore of the gypsum casts, unlike when chlorhexidine is added to the powder or a chlorhexidine solution is mixed with the material powder.

\section{Conclusions}

According to the results obtained in this study, one can conclude that mouthrinse with 0.12 and $0.2 \%$ chlorhexidine, before impression taking procedures, reduced the degree of contamination. Also, $0.2 \%$ chlorhexidine was statistically superior to $0.12 \%$ and can be recommended as the concentration for such a procedure. However, further studies are indispensable for proving this recommendation.
References
1. Casemiro LA, Martins CH, Souza FCPP, Panzeri H, Ito IY. Bacterial, fungal and yeast in six brands of irreversible hydrocolloid impression materials. Braz Oral Res 2007;21:323-9.

2. Ueda C, Modaforre PM. Moldagens com alginato - tratamento de superficie e uso racional da cuba umidificadora. PCL 2001;19:309-13.

3. Gjermo P. Chlorhexidine in dental pratice. J Clin Periodontal Res 1974;1:143-52.

4. Jones CG. Chlorhexidine: is it still the gold standard? Periodontology 2000 1997; 15:55-62.

5. Moran JM. Home-use oral hygiene products: mouthrinses. Periodontology 2000 2008;48:42-53

6. Schiott CR, Loe H, Briner WN. Two years use of chlorhexidine on man II. The effect of salivary oral. J Periodont Res 1976;11:158-64.

7. Ferraz CCR, Gomes BPFA, Zaia AA, Texeira FB, Souza-Filho FJ, Comparative study of the antimicrobial efficacy of chlorhexidine gel, chlorhexidine solution and sodium hupochlorite as endodontic irrigants. Braz Dent J 2007;18:294-8.

8. Ferreira FV, Angonese MP, Friedrich HC, Weiss RDN, Friedrich RS, Praetzel JR. Antimicrobial action of root canal filling pastes used in deciduous teeth. Rev Odonto Cienc 2010; 25:65-8.

9. Jenkins $S$, Addy M, Wade W. The mechanism of action of chlorhexidine. A study of plaque growth on enamel "in vivo". J Clin Periodontol 1998;15:415-24.

10. Moura CDVS, França FMG, Martins GAS, Feltrin PP, Zanetti RV. Disinfection of irreversible hydrocolloid impressions with sodium hypochlorite steam: Assessment antimicrobial efficacy. Rev Odont Cienc 2010;25:182-9.

11. Zanela NLM, Bijella MTT, Rosa OPS. The influence of mouthrinses with antimicrobial solution on the inhibition of the dental plaque and the levels of mutans streptococci in children. Pesq Odontol Bras 2002;16:101-6.

12. Quirynen M, Avontroodt P, Peeters W, Pauwels M, Coucke W, Van Steenberghe D. Effect of different chlorhedidine formulations in mouthrinses on plaque formation. J Clin Periodontol 2001;28:1 127-36.

13. Segreto et al. A comparison of mouthrinses containing two concentrations of chlorhexidine. J Periodontal Res 1986;23-32.

14. Smith RG, Moran J, Addy M, Doherty F, Newcomhe RG. Comparative staining in vitro and plaque inhibitory properties in vivo of $0.12 \%$ and $0.2 \%$ chlorhexidine mouthrinses. J Clin Periodontol 1995;22:63-17.

15. Sreenivasan PK, Gittins E. Effects of low dose chlorhexidine mouthrinses on oral bacteria and salivary microflora including those producing hydrogen sulfide. Oral Microbiol Immunol 2004;19:309-13. 
16. Samaranayake LP, Hunjan M, Jennings KJ. Carriage of oral flora on irreversible hydrocolloid and elastomeric impression materials. J Prosthet Dent 1991;65:244-9.

17. Herrera D, Roldan S, Santacruz I, Santos S, Masdevall M, Sanz M. Differences in antimicrobial activity of four commercial $0.12 \%$ chlorhexidine mouthrinses formulations: an in vitro contact test and salivary bacterial counts study. J Clin Periodontol 2003;30: 307-14.

18. Cancro LP, Paulovich DB, Bolton S, Picozzi A. Dose response of chlorhexidine gluconate in a model in vivo plaque system. J Dent Res 1974;53:765.

19. Keijser JAM, Verkade H, Timmerman MF, Van der Weidjen FA. Comparison of a 2 commercially available mouthrinses. J Periodontol 2003;74:214-8.

20. Casemiro LA, Souza FCPP, Panzeri H, Martins CH, Ito IY. In vitro antimicrobial activity of irreversible hydrocolloid impressions against 12 oral microorganisms. Braz Oral Res 2007;21:323-9 